\title{
STUDI FENOMENOLOGI: ORANG DENGAN HIV AIDS (ODHA) DALAM MENJALANI SELF-DISCLOSURE DI WILAYAH KERJA PUSKESMAS BONGAS
}

\author{
Wenny Nugrahati Carsita ${ }^{1}$, Indah Winarni ${ }^{2}$, Retno Lestari ${ }^{3}$ \\ ${ }^{1}$ Program Studi IImu Keperawatan STIKes Indramayu \\ ${ }^{2}$ Fakultas IImu Budaya Universitas Brawijaya \\ ${ }^{3}$ Program Studi Magister Keperawatan Fakultas Kedokteran Universitas Brawijaya
}

\begin{abstract}
ABSTRAK
HIV AIDS merupakan salah satu masalah terbesar bagi tenaga kesehatan maupun pemberi perawatan lainnya. Pada ODHA, tidak hanya mengalami penderitaan fisik karena proses penyakit, melainkan juga penderitaan psikososial yang disebabkan self-disclosure. Orang dengan HIV AIDS (ODHA) sering dihadapkan pada kondisi yang rumit untuk mengungkapkan atau menyembunyikan kondisi penyakit. Tujuan penelitian ini adalah untuk mengeksplorasi makna pengalaman ODHA dalam menjalani self-disclosure. Desain penelitian yang digunakan adalah kualitatif dengan pendekatan fenomenologi interpretif. Pengambilan data dilakukan dengan wawancara mendalam pada 7 ODHA yang memiliki pengalaman mengungkapkan status HIV, gejala penyakit dan faktor resiko kepada petugas kesehatan. Hasil penelitian dianalisis dengan metode Van Manen. Sepuluh tema telah teridentifikasi dalam penelitian ini, yaitu: (1) memercayai penyakit HIV AIDS mudah menular dan menakutkan, (2) mengalami masalah kesehatan fisik, (3) mengalami penderitaan batin, (4) ingin terbebas dari penderitaan fisik dan batin, (5) mencari dukungan, (6) tergugah dengan arahan petugas kesehatan (7) memercayai penyakit HIV AIDS tidak mudah menular dan ada harapan untuk menjalani hidup, (8) mendapat saran untuk terus berobat, (9) merasa terbebas dari tekanan, (10) melakukan kegiatan untuk meningkatkan kualitas hidup. Pengalaman ODHA dalam menjalani self-disclosure merupakan proses yang tidak mudah. Keseluruhan proses yang dilalui oleh ODHA seperti mengalami masalah kesehatan fisik dan penderitaan batin, hingga muncul sebuah harapan dan ODHA memutuskan untuk mencari dukungan, memahami penyakit HIV AIDS, menjalani pengobatan dan melakukan kegiatan untuk meningkatkan kualitas hidup dapat diinterpretasikan bahwa makna pengalaman ODHA dalam menjalani self-disclosure adalah dari keterpurukan menyandang ODHA menuju peningkatan kualitas hidup.
\end{abstract}

Kata Kunci: studi fenomenologi, ODHA, menjalani self-disclosure, Puskesmas

\begin{abstract}
HIV AIDS is one of the biggest problems for health workers and other care givers. In people living with HIV AIDS (PLWHA), not only suffered physically because of the disease process, but also the psychosocial suffering caused self-disclosure. PLWHA are often faced with the tricky conditions to reveal or hide the disease condition. The aim of this study is to explore the meaning of the experience of PLWHA in undergoing self-disclosure. This study used a qualitative research design using interpretive phenomenological approach. Data were collected by in-depth interviews in 7 PLWHA who have experience reveals HIV status, symptoms of the disease and risk factors to health workers. The results were analyzed by Van Manen method. Ten themes were identified in this study namely: (1) trust the HIV disease AIDS is contagious and scary, (2) experiencing physical health problems, (3) experiencing mental suffering, (4) want to be free from physical and mental suffering, (5) seeking support, (6) intrigued by the direction of health workers, (7) trust the HIV AIDS disease is not contagious and there is hope to live, (8) got a suggestion to continue treatment, (9) feel free from pressure, and (10) conducting activities to improve the quality of life. PLWHA experience in undergoing self-disclosure is a process that is not easy. The entire process undergone by PLWHA such as experiencing physical health problems and mental suffering, until emerged as a hope and PLWHA decided to seek support, understood HIV AIDS disease, conducting treatment, and conducting activities to improve the quality of life can be interpreted from adversity bear PLWHA towards improving the quality of life.
\end{abstract}

Keywords: Study phenomenology, PLWHA, undergoing self-disclosure, community health center

Jurnal IImu Keperawatan, Vol: 4, No. 2; Korespondensi : Wenny Nugrahati Carsita. Program Studi IImu Keperawatan STIKes Indramayu, Alamat: Jl. Wirapati Sindang Indramayu 45222. No. telp: (0234) 272020. Email: wennynugraha16@gmail.com 


\section{PENDAHULUAN}

HIV AIDS merupakan salah satu masalah terbesar bagi tenaga kesehatan maupun pemberi perawatan lainnya. Pada ODHA, tidak hanya mengalami penderitaan fisik karena proses penyakit, melainkan juga penderitaan pada fungsi psikososial. Pada ODHA, tidak hanya mengalami penderitaan fisik karena proses penyakit, melainkan juga penderitaan psikososial yang disebabkan selfdisclosure (Chaudoir et al., 2011).

Orang dengan HIV AIDS (ODHA) sering dihadapkan pada kondisi yang rumit apakah harus mengungkapkan atau menyembunyikan kondisi penyakit. Menyembunyikan kondisi penyakit dapat mengakibatkan penderitaan batin yang dirasakan sangat menyiksa karena beban menjaga rahasia (Rouleau et al., 2012). Di sisi lain, mengungkapkan kondisi penyakit juga dapat menimbulkan permasalahan seperti penolakan (Chaudoir et al., 2011). Menurut Devito (2013) salah satu faktor yang mempengaruhi individu melakukan pengungkapan adalah siapa pendengar yang akan diberikan informasi, sehingga selfdisclosure cenderung dilakukan kepada orang yang dianggap dapat dipercaya, dekat, dan disukai. Hua et al. (2014) mengungkapkan self-disclosure pada ODHA biasanya dilakukan hanya kepada orang yang dianggap dipercaya dan mampu memberikan perawatan salah satunya adalah petugas kesehatan.
Rasa percaya bahwa petugas kesehatan dapat memberikan pengobatan dan perawatan yang diperlukan merupakan salah satu alasan ODHA memiliki keharusan untuk melakukan self-disclosure (Stutterheim et al., 2014). ODHA juga memercayai bahwa petugas kesehatan memiliki pengetahuan yang luas tentang penyakitnya, sehingga tidak akan memberikan reaksi negatif (Chen et al., 2007; Stutterheim et al., 2016). Selain itu, umumnya self-disclosure dilakukan oleh ODHA dengan mempertimbangkan keuntungan dan kerugian. Keuntungan self-disclosure telah banyak diungkapkan di antaranya membantu ODHA mendapatkan dukungan, kesehatan fisik dan mental yang lebih baik, dan meningkatkan kepatuhan terhadap pengobatan ARV (Stutterheim et al., 2016). Self-disclosure juga dilaporkan dapat memberikan kesempatan ODHA untuk mengekspresikan pikiran dan perasaan, meningkatkan kepercayaan diri, serta menjadi komponen penting dalam membangun hubungan ODHA dengan petugas kesehatan (Chaudoir \& Fisher, 2010).

Self-disclosure merupakan proses yang sulit dan menantang (Arrey et al., 2015). Perasaan takut mendapatkan penilaian negatif merupakan salah satu alasan ODHA tidak melakukan self-disclosure (Bird \& Voisin, 2013). Ketakutan tersebut mengakibatkan ODHA menunda atau menghindari 
pengobatan (Stutterheim et al., 2014). Ketakutan tersebut juga berdampak pada psikologis ODHA dimana ODHA merasa tidak layak mendapatkan perawatan dan motivasi untuk sehat berkurang (Rahmati-Najarkolaei et al., 2010). Hal tersebut tentu akan berpengaruh terhadap perburukan kondisi kesehatan yang dapat mempercepat kematian ODHA. Oleh karena itu, selfdisclosure adalah penting sebagai langkah awal ODHA memperoleh pengobatan dan mengetahui informasi tentang penyakit dari gejala, cara penularan serta faktor resiko. Selain itu, self-diclosure juga membantu petugas kesehatan mengetahui jumlah penderita HIV yang belum terdeteksi, sehingga baik ODHA maupun petugas kesehatan dapat membantu pencegahan penularan HIV (Arrey et al., 2015).

Pada tahun 2012, Kabupaten Indramayu memiliki jumlah kasus HIV/AIDS terbanyak di Provinsi Jawa Barat yaitu 451 kasus (Bidang PLPP Dinas Kesehatan Provinsi Jawa Barat, 2012). Untuk mengatasi penyebarannya, beberapa Puskesmas dan Rumah Sakit telah disediakan fasilitas untuk memberikan layanan dasar HIV dan IMS di antaranya adalah Puskesmas Bongas (Lilis, 2015). Petugas kesehatan di Puskesmas Bongas mengungkapkan kadang mengalami kesulitan untuk membantu ODHA melakukan selfdisclosure karena ODHA menolak kehadiran petugas kesehatan. Selain itu, petugas kesehatan juga merasa tidak enak hati karena permasalahan HIV AIDS dianggap topik yang sensitif. ODHA yang menutup diri dari petugas kesehatan, tidak mau menerima keadaan, dan tidak mau menjalani pengobatan biasanya mengalami perburukan kondisi kesehatan dan meninggal.

Beberapa penelitian telah banyak mengungkapkan pengalaman self-disclosure kepada selain petugas kesehatan. Namun, masih sedikit ditemukan penelitian yang mengeksplorasi pengalaman ODHA menjalani self-disclosure kepada petugas kesehatan. Hasil penelitian sebelumnya belum mengeksplorasi pengalaman ODHA secara lengkap melainkan terbatas pada pengalaman perspektif ODHA tentang pengungkapan. Oleh karena itu, peneliti merasa tertarik untuk melakukan penelitian mengenai pengalaman ODHA menjalani self-disclosure untuk memperoleh gambaran pengalaman ODHA secara detail. Tujuan penelitian ini adalah untuk mengeksplorasi makna pengalaman ODHA dalam menjalani self-disclosure di wilayah kerja Puskesmas Bongas.

\section{METODE}

Penelitian ini menggunakan desain penelitian kualitatif dengan menggunakan pendekatan fenomenologi interpretif (Streubert, \& Carpenter, 2011). Penelitian ini dilaksanakan di wilayah kerja Puskesmas Bongas Kabupaten www.jik.ub.ac.id 
Indramayu. Jumlah partisipan dalam penelitian ini adalah 7 (tujuh) partisipan. Partisipan dalam penelitian ini adalah ODHA yang memiliki pengalaman mengungkapkan status HIV, gejala penyakit dan faktor resiko kepada petugas kesehatan, mampu mengungkapkan pengalamannya secara detail, dan bersedia menjadi partisipan. Ketujuh partisipan dipilih dengan cara peneliti berdiskusi dengan petugas kesehatan untuk mengidentifikasi ODHA yang dapat memenuhi kriteria tersebut. Pada awal identifikasi, peneliti dan petugas kesehatan memperoleh lima belas partisipan, namun terdapat satu partisipan menolak untuk berpartisipasi dalam penelitian, dua partisipan sedang bekerja di luar kota, dan satu partisipan sedang menjalani tes lanjutan di rumah sakit. Saat melakukan wawancara, dari ketujuh partisipan sudah tidak ditemukan lagi variasi data sehingga peneliti memutuskan untuk tidak melibatkan partisipan selanjutnya dalam pengambilan data.

Sebelum melakukan wawancara peneliti dengan didampingi petugas kesehatan mendatangi rumah partisipan untuk memperkenalkan diri, menjelaskan, tujuan, dan manfaat penelitian. Kemudian peneliti melakukan kontrak waktu dan tempat sesuai dengan kesepakatan dari partisipan. Kemudian peneliti melakukan wawancara dengan menggunakan teknik in depth interview selama 30 - 60 menit di rumah Jurnal IImu Keperawatan - Volume 4, No. 2 November 2016 partisipan. Hasil penelitian dianalisis dengan metode Van Manen melalui tiga pendekatan yaitu holistik, selektif, dan rinci. Penelitian ini telah mendapatkan rekomendasi persetujuan etik oleh Komite Etik Politeknik Kesehatan Kemenkes Malang.

\section{HASIL}

Hasil penelitian diperoleh sepuluh tema yaitu: (1) mempercayai penyakit HIV AIDS mudah menular dan menakutkan, (2) mengalami masalah kesehatan fisik, (3) mengalami penderitaan batin, (4) ingin terbebas dari penderitaan fisik dan batin, (5) mencari dukungan, (6) tergugah dengan arahan petugas kesehatan (7) mempercayai penyakit HIV AIDS tidak mudah menular dan ada harapan untuk menjalani hidup, (8) mendapat saran untuk terus berobat, (9) merasa terbebas dari tekanan, (10) melakukan kegiatan untuk meningkatkan kualitas hidup.

\section{Tema 1: Memercayai penyakit HIV AIDS} mudah menular dan menakutkan

Penyakit HIV AIDS dipercaya oleh partisipan sebagai penyakit yang mudah menular dan menakutkan. Tema ini disusun dari dua sub tema yaitu mudah ditularkan dan mengancam keselamatan jiwa.

Sub tema mudah ditularkan diungkapkan oleh partisipan sebagai penyakit yang mudah ditularkan kepada orang lain melalui kontak biasa. Hal tersebut didukung oleh pernyataan 
partisipan sebagai berikut:

P1: Ya kan wong awam ya, pertama weruh mengkonon jare sing ya baka nempel bae gah nular, kan lagi pertama kan ya kita gah wedi (Ya kan orang awam ya, pertama tahu itu katanya yang kalau nempel saja menular, kan waktu pertama saya juga takut)"

Sub tema kedua adalah mengancam keselamatan jiwa. Mengancam keselamatan jiwa diungkapkan oleh partisipan sebagai sesuatu yang menyebabkan penderitaan berkepanjangan. Penderitaan berkepanjangan diungkapkan partisipan sebagai sesuatu yang menyeramkan, tidak ada penyelesaian, ungkapan ketakutan. Hal tersebut didukung oleh pernyataan partisipan sebagai berikut:

P2: “...termasuk bibie dewek bae gah kaya seolah-olah ketakutan apa, menyeramkan lah istilahe kuh (Ya..kan seperti orang lain termasuk bibi sendiri juga seperti seolaholah ketakutan apa, menyeramkan lah istilahnya tuh)"

P5: "Maune mah embuh bae orah bu laralara gah biasa bae orah, temu-temu ya Allah kosi penyakite gede banget, temutemu berobate seumur hidup (Tadinya mah ngga tahu kan bu sakit-sakit juga biasa saja, tiba-tiba Ya Allah penyakitnya besar sekali, tiba-tiba berobatnya seumur hidup)"

P2: "Seweruhe kita kan bengen kita mah endah gah wis pirang tahun, 2009 terinfeksi kuh...Dadi kuh, ah...pasti kita kuh mati, pasti kita kuh mati (Setahu saya kan dulu saya mah soalnya sudah berapa tahun, 2009 terinfeksi tuh...jadi, ah..pasti saya tuh meninggal, pasti saya tuh meninggal)"

\section{Tema 2: Mengalami Masalah Kesehatan Fisik}

Partisipan mengungkapkan penyakit HIV AIDS mengakibatkan partisipan mengalami masalah kesehatan fisik. Masalah kesehatan fisik berarti terganggunya kondisi kesehatan fisik karena munculnya gejala klinis penyakit. Tema ini disusun dari sub tema yaitu mengalami gejala klinis penyakit.

Sub tema mengalami gejala klinis penyakit diungkapkan oleh partisipan melalui gangguan pola makan, gangguan pada kulit, gangguan penglihatan, demam, dan kelemahan. Hal ini didukung oleh pernyataan partisipan sebagai berikut:

P7: "Ya..awale mah kerja berat, ngelektor orah, aturan istirahat beli istirahat, ngedrop kula sampe setengah bulan beli mangan (Ya...awalnya mah kerja berat, traktor kan, aturan istirahat ngga istirahat, ngedrop saya sampai setengah bulan ngga makan)".

P7: "Maune awak gering pisan, bobote reang 57, 56, sampe kari 44 kilo (Tadinya badan kurus banget, beratnya saya 57, 56, sampai tinggal $44 \mathrm{~kg})^{\prime \prime}$

www.jik.ub.ac.id 
P1: "Gatelan, gatele kaya cacar mengkonon (Gatal, gatalnya seperti cacar begitu)".

P3: "Ngedrop kuh ora pada ireng, kurus, ora kaya wong sejen orah, dadi matane kuh abang, ora katon, abu kabeh (Ngedrop tuh ngga pada hitam, kurus, seperti orang lain kan, jadi matanya merah, ngga bisa melihat, bengkak semua)"

P2: "Kita kuh periksa, ari awan meriang, ngerasakena baka awan atis (Saya tuh periksa, kalau siang meriang, ngerasain kalau siang dingin)"

P4: "Ya..lemes, blenak, lemes. Ya..lemah beh saya menurun konon kah badan kuh (Ya..lemas, ngga enak, lemas. Ya..lemah aja semakin menurun badan tuh)".

\section{Tema 3: Mengalami Penderitaan Batin}

Partisipan mengungkapkan penyakit HIV AIDS mengakibatkan partisipan mengalami penderitaan, kesengsaraan pada batin. Tema ini disusun dari enam sub tema yaitu merasa tidak tenang, merasa berduka, merasa menyangkal kondisi yang dialami, merasa tidak enak hati, merasa tidak berdaya, dan merasa tertekan.

Sub tema merasa tidak tenang diungkapkan oleh partisipan sebagai perasaan takut. Perasaan takut diungkapkan sebagai perasaan takut menularkan, takut dengan kondisi penyakit dan kematian, dan khawatir penilaian orang lain. Hal ini didukung oleh pernyataan partisipan sebagai berikut:

P1: "pertama weruh mengkonon jare sing ya baka nempel bae gah nular, kan lagi pertama kan ya kita gah wedi dewek, melang nularena orah (pertama tahu begitu katanya yang kalau nempel saja menular, kan waktu pertama kan saya juga takut sendiri, takut menularkan)"

P2: “...ya Allah kita duene penyakit mengkenen bakal mati, ya..deg-degan, apa maning ning wong tua priwe.. (...ya Allah saya punya penyakit begini akan mati, ya..deg-degan, apalagi sama orang tua gimana..)" (p2)

P5: “...cangkeme wong kan sejen-sejen, ana sing positif, sing negatif, kaya konon watire kuh. Engko sing mblesakena kan ya...kuh kaya kenen kaya kenen.. (...mulutnya orang kan beda-beda, ada yang positif, yang negatif, seperti itu khawatirnya tuh. Nanti yang menjelekkan kan ya..tuh seperti ini seperti ini)" (p5)

Sub tema merasa berduka diungkapkan oleh partisipan sebagai perasaan sedih. Hal ini didukung oleh pernyataan partisipan sebagai berikut:

P1: "Ya..selama pertama-tama kuene mah ngerasa ngenes ya, ngenes ana, pasti ngenes (Ya..selama pertama-tama itunya mah ngerasa sedih ya, sedih ada, pasti sedih)". 
Sub tema merasa menyangkal kondisi yang dialami diungkapkan oleh partisipan sebagai perasaan marah. Perasaan marah diungkapkan oleh partisipan sebagai perasaan marah, tidak percaya, dan tidak menerima kondisi yang dialami. Hal ini didukung oleh pernyataan partisipan sebagai berikut:

P5: "Nyewot bae kah bu, ngegerundel bae (Marah aja bu, menggerutu terus)".

P5: "Ora percaya kita kenang penyakit kaya kenen kuh. Maune mah embuh bae orah bu lara-lara gah biasa bae orah ( $\underline{N g g a}$ percaya saya kena penyakit begini tuh. Tadinya mah ngga tau kan bu saki-sakit juga biasa saja)".

P4: "Dadi ora, ora..lamon anu mah ora nerima, meneng bae (Jadi ngga...ngga..seandainya itu mah $\underline{n g g a}$ menerima, diam aja)".

Sub tema merasa tidak enak hati diungkapkan oleh partisipan sebagai perasaan malu. Hal ini didukung oleh pernyataan partisipan sebagai berikut:

P1: “...pertama-tama mah ya mengkonon, isin ya.. kita ngobrol bae gah isin, ya mbuh temen wonge weruh belihe mah, cuma kita kuh isin dewek kah (...pertama-tama mah ya begitu, malu ya.. Saya ngobrol aja malu, ya ngga tahu orang tahu ngganya mah, cuma saya tuh malu sendiri)".
Sub tema merasa tidak berdaya diungkapkan oleh partisipan sebagai perasaan pasrah. Hal ini didukung oleh pernyataan partisipan sebagai berikut:

P2: "Tapi kita mah wis pasrah, wis kita kuh aja diobati (Tapi saya mah sudah pasrah, sudah saya tuh jangan diobati)" (p2)

Selain pasrah, merasa tidak berdaya juga diungkapkan partisipan sebagai perasaan tidak ada harapan. Tidak ada harapan diungkapkan partisipan sebagai perasaan tidak ada artinya hidup. Hal ini didukung oleh pernyataan partisipan sebagai berikut:

P1: "Rasane kuh kaya wis....kaya kiamat lah jare dewek mah mengkonon, kayane kuh ya wis lah beli bisa apa-apa (Rasanya tuh seperti sudah...seperti kiamat lah kata saya mah begitu, sepertinya tuh sudah lah ngga bisa apa-apa)".

Sub tema merasa tertekan diungkapkan oleh partisipan sebagai perasaan tidak nyaman. Perasaan tidak nyaman diungkapkan partisipan dalam bentuk pernyataan mempunyai beban pikiran. Hal ini didukung oleh pernyataan partisipan sebagai berikut:

P2: "Ya..perasaane duwe beban, ya Allah kita duene penyakit mengkenen bakal mati. Ya..deg-degan apa maning ning wong tua priwe (Ya..perasaannya punya beban, ya Allah saya punya penyakit begini 
akan mati. Ya..deg-degan apa lagi sama orang tua gimana)"

Selain mempunyai beban, merasa tidak nyaman juga diungkapkan partisipan sebagai perasaan tidak menentu. Hal ini didukung oleh pernyataan partisipan sebagai berikut:

P5: "Ya..campur aduk, keringet bae gede cilik, ya ora weruh ya bu maune (Ya..campur aduk, keringat saja besar kecil, ya kan tidak tahu ya bu tadinya)".

\section{Tema 4: Ingin Terbebas dari Penderitaan Fisik dan Batin}

Partisipan mengungkapkan keinginan terbebas dari penderitaan fisik dan batin sebagai harapan. Bebas dari penderitaan berarti ODHA tidak merasakan kesengsaraan yang diakibatkan karena terganggunya kondisi kesehatan fisik dan batin. Tema ini disusun dari dua sub tema yaitu ingin kondisi kesehatan tidak terganggu dan ingin mendapatkan dukungan.

Sub tema ingin kondisi kesehatan tidak terganggu diungkapkan oleh partisipan sebagai keinginan untuk sehat. Keinginan untuk sehat diungkapkan partisipan sebagai keinginan untuk sembuh, sehat, kondisi kesehatan tidak memburuk. Hal tersebut didukung oleh pernyataan partisipan sebagai berikut:
P1: "Harapane ya sehat, wis kuen tujuane kita mengkonon (Harapannya ya sehat, sudah itu tujuan saya begitu)"

P4: "Ya...pengen sehat sih, pengen nganukena anak konon kah, pengen tua karo anak mengkonon (Ya..pengen sehat sih, pengen ngituin anak begitu, pengen tua bersama anak)" (Nganukena anak adalah merawat anak)

Sub tema ingin mendapatkan dukungan diungkapkan oleh partisipan melalui keinginan memperoleh pengobatan dan mendapatkan informasi tentang penyakit. Hal tersebut didukung oleh pernyataan partisipan sebagai berikut:

P1: "Ya..amberan olih tindakan selanjutnya lah istilahe mah mengkonon, terus kita pengen priwe wis positif kuh Ya..supaya dapat tindakan selanjutnya lah istilahnya mah begitu, terus saya mau gimana sudah positif tuh)"

P6: "Pengen olih obat amber sehat (Ya..supaya dikasih obat, ingin dapat obat supaya sehat)".

P5: "Pengen weruh penyakit apa, nang apa, mengkonon, berobat orah bu (ingin tahu penyakit apa, kenapa, begitu, berobat kan bu)"

\section{Tema 5: Mencari Dukungan}

Mencari dukungan diungkapkan sebagai 
tindakan yang dilakukan untuk menanggulangi penderitaan akibat HIV AIDS. Tema ini disusun dari dua sub tema yaitu mencari tahu masalah kesehatan yang dialami dan menceritakan masalah yang dialami.

Sub tema mencari tahu masalah kesehatan yang dialami diungkapkan partisipan sebagai tindakan pergi ke tempat pelayanan kesehatan. Hal tersebut didukung oleh pernyataan partisipan sebagai berikut:

P1: "Suwe-suwene kita meng Puskesmas periksa, barang durung dites dadi dikira gatelan biasa kongkon periksa ning dokter kulit (Lama-lama saya ke Puskesmas periksa, terus belum dites jadi dikira gatal biasa disuruh periksa ke dokter kulit)".

Tindakan memeriksakan kondisi kesehatan juga diungkapkan ODHA sebagai tindakan mencari tahu masalah kesehatan yang dialami Hal tersebut didukung oleh pernyataan partisipan sebagai berikut:

P2: “...dadi mono beli sengaja nanggo periksa B20. Kita kuh periksa ari awan meriang, ngerasakena baka awan atis kuh penyakit apa (...jadi ke sana tuh ngga sengaja buat periksa B20. Saya tuh periksa kalau siang meriang, kalau siang dingin tuh penyakit apa)" (Ke sana adalah pergi ke Puskesmas)

P5: "Wong lanang mangane ora nafsu bae, mangane secentong bae ora entok, angel, terus periksa ning mantri $H . Y$, cerita apa (Suami makannya ngga nafsu terus, makannya 1 centong saja ngga habis, terus periksa sama mantri H.Y)" (p5)

Sub tema menceritakan masalah yang dialami diungkapkan partisipan sebagai tindakan bercerita kepada petugas kesehatan. Hal tersebut didukung oleh pernyataan partisipan sebagai berikut:

P7: "Ya..kan pas ngedrop, cerita ning majikan kula kan kerjane ning Puskesmas, ngerti orah penyakit mengkenen, dadi dikongkon mana tes bae meng Puskesmas (Ya..kan pas ngedrop, cerita ke majikan saya kan kerjanya di Puskesmas, ngerti kan penyakit begini, jadi disuruh sana tes saja ke Puskesmas)".

Bercerita kepada keluarga juga diungkapkan partisipan sebagai tindakan menceritakan masalah yang dialami. Hal tersebut didukung oleh pernyataan partisipan sebagai berikut:

P1: "Ya....kita gah pertama-tama kan kanda ning mboke kita (Ya..saya juga pertama-tama kan cerita ke ibu saya)".

\section{Tema 6: Tergugah dengan Arahan Petugas \\ Kesehatan}

Partisipan mengungkapkan tergugah dengan arahan petugas kesehatan untuk melakukan pengobatan ke Puskesmas. Tema ini disusun dari sub tema yaitu merasa tergerak untuk melakukan pengobatan ke Puskesmas.

www.jik.ub.ac.id 
Sub tema merasa tergerak untuk melakukan pengobatan ke Puskesmas diungkapkan partisipan bahwa partisipan mendapatkan dukungan dari petugas kesehatan. Mendapatkan dukungan dari petugas kesehatan diungkapkan bahwa partisipan disuruh pergi ke Puskesmas. Hal tersebut didukung oleh pernyataan partisipan sebagai berikut:

P7: "Majikan kula kan kerjane ning Puskesmas, ngerti orah penyakit mengkenen, dadi dikongkon mana tes bae meng Puskesmas...anu, penasaran, mana ah. Reang kuh miang meng Puskesmas, periksa, terus dimet darahe (Majikan saya kan kerjanya di Puskesmas, mengerti penyakit begini, jadi disuruh tes saja ke Puskesmas...anu, penasaran, ke sana ah. Saya tuh pergi ke Puskesmas, periksa, terus diambil darahnya)"

Mendapatkan dukungan dari petugas kesehatan juga diungkapkan oleh partisipan bahwa partisipan disuruh berobat. Hal tersebut didukung oleh pernyataan partisipan sebagai berikut:

P6: "...barang digawa, ning lbu $M$ ning Puskesmas kuh pas dicek darahe, Jare Ibu M e langsung berobat bareng, dadi kita berobat bareng (..terus dibawa, sama Ibu di Puskesmas tuh pas dicek darahnya, kata Ibu $M$ nya langsung berobat bareng, jadi saya berobat bareng)"
Selain disuruh pergi ke Puskesmas, disuruh berobat, partisipan juga mengungkapkan mendapatkan dukungan dari petugas kesehatan bahwa partisipan disuruh untuk melakukan tes. Hal tersebut didukung oleh pernyataan partisipan sebagai berikut:

P2: "Barang doktere kan curigae mono, mbuh kitae mah ora kepikiran apa-apa. Jare Ibune kuh, "Mba, sekalian ya bari tes?", ya wis orah ya jare kita kuh sing penting mah kita kuh demi kebaikan, sehat orah (Terus dokternya kan curiganya ke situ, ngga tahu sayanya mah ngga kepikiran apa-apa. Kata Ibunya tuh, "Mba, sekalian ya sama tes?", ya sudah kan ya kata saya tuh yang penting demi kebaikan, sehat kan)

\section{Tema 7: Memercayai Penyakit HIV AIDS} Tidak Mudah Menular dan Ada Harapan untuk Menjalani Hidup

Partisipan memercayai penyakit HIV AIDS tidak mudah menular dan ada harapan untuk menjalani hidup setelah mendapatkan penjelasan dari petugas kesehatan. Tidak mudah ditularkan berarti penyakit HIV AIDS tidak ditularkan melalui kontak biasa. Ada harapan untuk menjalani hidup berarti ada solusi bagi penderita HIV AIDS untuk tetap menjalani hidup. Tema ini disusun dari dua sub tema yaitu tidak ditularkan melalui kontak biasa dan ada solusi. 
Sub tema tidak ditularkan melalui kontak biasa diungkapkan oleh partisipan bahwa penyakit HIV AIDS memiliki cara penularan tertentu. Memiliki cara penularan tertentu berarti bahwa tidak semua penyakit menular memiliki cara penularan yang sama. Hal tersebut didukung oleh pernyataan partisipan sebagai berikut:

P6: "Penyakit mengkenen kuh kader gah dodok bareng apa ora nular (penyakit begini tuh duduk bareng apa tidak menular)".

P1: "Cuman ya..terus dijelasena ning dokter karo mboke, meskipun minum bareng segelas, mangan bareng beli nular, nulare hanya tertentu-tertentu bae, beli gampang nular, hanya ya..melakukan mengkonon, kari mangan bareng ora, nulare hanya tertentutertentu bae (Cuman ya..terus dijelasin dokter sama ibu saya, meskipun minum bareng satu gelas, makan bareng, tidak menular, menularnya hanya ya..melakukan begitu, kalau makan bareng ngga, menularnya hanya tertentu-tertentu saja)"

Sub tema ada solusi diungkapkan oleh partisipan bahwa menderita penyakit HIV AIDS, bukan berarti ODHA sudah tidak bisa beraktivitas. Masih bisa beraktivitas diungkapkan bahwa ODHA bisa sehat dan bisa bekerja. Hal tersebut didukung oleh pernyataan partisipan sebagai berikut:

P6: "...berobat berjalan, berobat aja ana mandege, kogah waras ari rutin mah (...berobat berjalan, berobat jangan berhenti, nanti juga sehat kalau rutin $\underline{m a h)^{\prime \prime}}$

P1: “...berpikir positif bae, soale akeh sing positif tapi sehat gah (...berpikir positif aja, soalnya banyak yang positif tapi sehat juga)"

Tema 8: Mendapat Saran untuk Terus

\section{Berobat}

Selama self-disclosure partisipan mendapat saran untuk terus berobat. Tema ini disusun dari tiga sub tema yaitu memperoleh dukungan emosional, memperoleh dukungan untuk melakukan pengobatan, memperoleh rasa aman.

Sub tema memperoleh dukungan emosional diungkapkan partisipan dalam bentuk perhatian dari petugas kesehatan. Perhatian yang diperoleh diungkapkan partisipan dalam bentuk nasihat dari petugas kesehatan. Hal ini didukung oleh pernyataan partisipan sebagai berikut:

$P 1:$ "...ingat yang diomongin dokter tuh ya, "penyakit ini ngga bisa sembuh, tapi pasiennya berhak untuk sehat (...ingat yang diomongin dokter tuh ya, penyakit ini 
ngga bisa sembuh, tapi pasiennya berhak untuk sehat)"

Sub tema mendapatkan dukungan untuk menjalani pengobatan diungkapkan partisipan dimana partisipan diarahkan untuk melakukan pengobatan lanjutan. Diarahkan untuk melakukan pengobatan lanjutan diungkapkan bahwa partisipan disuruh pergi ke rumah sakitt. Hal ini didukung oleh pernyataan partisipan sebagai berikut:

P1: "Kongkon mana bae berobat, engko gah ning kana ketemu karo wong sing pada, ya kan engko amber bisa ngobrolngobrol (Suruh ke sana saja berobat, nanti juga di sana bertemu sama orang yang sama, ya kan nanti supaya bisa ngobrolngobrol)" (p1) (Suruh ke sana adalah Setelah dari Puskesmas partisipan disuruh untuk melakukan pengobatan lanjutan ke RS B)

Selain disuruh berobat, disuruh pergi ke Puskesmas juga diungkapkan partisipan sebagai ungkapan didorong untuk melakukan pengobatan. Hal ini didukung oleh pernyataan partisipan sebagai berikut:

P5: "Ning H. Y kongkon meng Puskesmas, terus kongkon dimet darahe (Sama H. Y disuruh ke Puskesmas, terus disuruh diambil darahnya)".

Sub tema memperoleh rasa aman diungkapkan partisipan memiliki harapan untuk hidup. Memiliki harapan untuk hidup diungkapkan bahwa partisipan bisa sehat. Hal ini didukung oleh pernyataan partisipan sebagai berikut:

P1: “...aja berpikir sing ora-ora dingin, berpikir positif bae, soale wis akeh sing positif tapi sehat gah (...jangan berpikir yang ngga-ngga dulu, berpikir positif aja, soalnya sudah banyak yang positif tapi sehat juga)".

Selain bisa sehat, bisa bekerja juga diungkapkan partisipan sebagai ungkapan memiliki harapan untuk hidup. Hal ini didukung oleh pernyataan partisipan sebagai berikut:

P6: "Dokter ngupahi saran kuh aja dipaksa, padane tanggung, engko ah molahe tanggung, aja, ya liren, bokat ngedrop dipaksa mah. Bisa molah maning kaya semula, tapi sing penting rutin minum obat setiap bulane mene (Dokter memberi saran tuh jangan dipaksa, misalkan nanggung, nanti ah kerjanya tanggung, jangan, ya istirahat, takut ngedrop dipaksa mah. Bisa kerja lagi seperti semula, tapi yang penting rutin minum obat setiap bulannya ke sini)" (p6)

\section{Tema 9: Merasa Terbebas dari Tekanan}

Merasa Terbebas dari tekanan diungkapkan partisipan sebagai perasaan nyaman, dan batin menjadi lebih baik setelah selfdisclosure. Tema ini disusun dari empat sub 
tema yaitu merasakan kenyamanan batin, merasa batin lebih baik, merasa ikhlas dengan kondisi penyakit, dan merasa optimis.

Sub tema merasakan kenyamanan batin diungkapkan partisipan sebagai kelegaan hati. Merasakan kelegaan hati diungkapkan dalam ungkapan perasaan lega dan tenang. Hal ini didukung oleh pernyataan partisipan sebagai berikut:

P4: "Ya..kan lega, banyak orang yang sama kaya saya tuh. Ya..seneng kaya konon kah artine kah ana sing ngedukung (Ya..kan lega, banyak orang yang sama seperti saya tuh. Ya...senang seperti itu kan artinya kan ada yang mendukung)" P6: “...berobat berjalan, berobat aja ana mandege, kogah waras ari rutin mah. Dadi atine kita kuh seger ya bu, seneng diomong mengkonon kuh (...berobat jalan, berobatnya tdak berhenti, nanti juga sembuh kalau rutin mah. Jadi hati saya tuh segar ya bu, senang diomongin begitu tuh)".

Sub tema merasa batin lebih baik diungkapkan partisipan dengan ungkapan mengalami pengurangan tekanan. Mengalami pengurangan tekanan diungkapkan dengan perasaan biasa saja oleh partisipan. Hal ini didukung oleh pernyataan partisipan sebagai berikut:

P2: “...istilahe kuh menjijikkan, tapi kan bagi kita sing ngerti apa mah, ora biasa bae (...istilahnya tuh menjijikkan, tapi bagi saya yang ngerti mah biasa saja)"
Sub tema merasa ikhlas dengan kondisi penyakit diungkapkan partisipan dengan ungkapan menerima kondisi penyakit. Hal ini didukung oleh pernyataan partisipan sebagai berikut:

P1: "..sharing apa orah, ngobrol-ngobrol, sue-suene kan kebuka pikirane kita kuh, jadi kuh oh ya wis iya sun kita gah beli papa (..sharing apa kan, ngobrol-ngobrol, lama-lama kan terbuka pikiran saya tuh, jadi tuh oh ya sudah iya saya juga ngga apa-apa)" (Ngga apa-apa merupakan ungkapan partisipan menerima kondisi penyakitnya setelah memperoleh masukan dan terbuka pikirannya)

Sub tema merasa optimis diungkapkan partisipan di mana partisipan merasa semangat mengatasi penyakit. $\mathrm{Hal}$ ini didukung oleh pernyataan partisipan sebagai berikut:

P5: "Lamon anu kah deweke ngelawan ning penyakit, aja sampe deweke nyerah (Kalau itu mah kitanya melawan penyakit, jangan sampai kita menyerah)".

P3: "Pas lihat kok banyak gitu, banyak teman-temannya, ya sudah semangat, pasti bisa sehat lagi".

\section{Tema 10: Melakukan Kegiatan untuk}

\section{Meningkatkan Kualitas Hidup}

Melakukan kegiatan untuk meningkatkan kualitas hidup diungkapkan partisipan sebagai kegiatan yang dapat memberikan kebaikan www.jik.ub.ac.id 
baik bagi ODHA maupun orang lain. Tema ini disusun dari tiga sub tema yaitu menjalani pengobatan, bergabung dalam kelompok dukungan, dan membantu orang lain.

Sub tema menjalani pengobatan diungkapkan partisipan melalui tindakan pergi ke tempat pelayanan kesehatan, melakukan pengobatan. Hal ini didukung oleh pernyataan partisipan sebagai berikut:

P7: "Sekien kuh bu kula mah dikongkon enggal minggu meng RS $B$ ya dijalani bae kula mah (Sekarang tuh bu saya mah disuruh tiap minggu ke RS B ya dijalani saja saya mah)"

P5: "...pengen sehat, dadine ya wis berobat bareng-bareng bae, wong kepribe sih, wong kepengen waras, pengen sehat orah bu, aja sampe menyerah lah (..pengen sehat, jadinya ya sudah berobat barengbareng saja, orang gimana sih, orang kepengen sembuh, pengen sehat kan bu, jangan sampai menyerah (ah)"

Sub tema bergabung dalam kelompok dukungan diungkapkan partisipan sebagai tindakan menjadi anggota dukungan sebaya. Hal ini didukung oleh pernyataan partisipan sebagai berikut:

P2: “...sampenan kita kuh ya istilahe dadi pegawai lapangan, home visit ning umahumah kah, ngasih support.. (...sampai saya tuh ya istilahnya jadi pegawai lapangan, home visit ke rumah-rumah, ngasih support..)"

Sub tema membantu orang lain diungkapkan partisipan melalui tindakan memberikan dukungan kepada ODHA. Hal ini didukung oleh pernyataan partisipan sebagai berikut:

P1: “...ning kana akeh orah wong pada penyakite mengkenen, dadi kuh sering berbagi pengalaman, sharing apa orah, ngobrol-ngobrol (...di sana kan banyak orang dengan penyakit begini, jadi tuh sering berbagi pengalaman, sharing apa kan, ngobrol-ngobrol)"

P3: “...nguwarahi sing lagi sakit kah minum obat sing bener (... menasihati yang sedang sakit minum obat yang benar)".

P2: "Ya...emang ya kita pernah ya dadi KDS, ngerujuk wong ning Puskesmas $K$, ngerujuk ning Puskesmas $K$ kuh kan kategori 2 TB e (Ya..memang ya saya pernah ya jadi KDS, merujuk orang ke Puskesmas K, merujuk ke Puskesmas K tuh kan ketegori 2 TB nya)"

\section{PEMBAHASAN}

Orang dengan HIV AIDS (ODHA) dihadapkan pada kondisi yang yang tidak mudah. Kondisi tersebut berasal dari masalah kesehatan fisik yang dialami karena gejala klinis penyakit, maupun permasalahan psikososial yang timbul karena ODHA tidak dapat melakukan self-disclosure atau masalah yang dihadapi setelah ODHA melakukan self-disclosure. Hasil 
penelitian diperoleh bahwa ODHA mengalami penderitaan batin. Arrey et al. (2015) mengungkapkan bahwa salah satu penderitaan batin yang dialami ODHA berasal dari perasaan takut dengan penilaian negatif dari orang lain apabila mengungkapkan kondisi penyakitnya. Chen et al. (2007) juga mengungkapkan bahwa ODHA merasa tertekan dengan kondisi yang dialami sehingga mengakibatkan penderitaan batin.

Penderitaan fisik dan batin yang dialami ODHA memunculkan harapan di mana ODHA ingin terbebas dari penderitaan fisik maupun batin. Yadav (2010) mengungkapkan harapan merupakan komponen penting dalam penanganan HIV AIDS. ODHA menyatakan bahwa setelah mengetahui kondisi penyakit, ODHA berharap akan menerima bantuan pengobatan, informasi tentang penyakit, dan dukungan emosional. Harapan tersebut mempengaruhi tindakan ODHA untuk mengatasi penderitaan.

Mencari dukungan merupakan tindakan yang dilakukan ODHA untuk mengatasi penderitaan yang disebabkan penyakit HIV AIDS. Mencari dukungan dilakukan oleh ODHA dengan mencari tahu dan menceritakan kondisi yang dialami. Thomas et al. (2009) mengungkapkan bahwa sebagian besar ODHA mencari perawatan ketika memiliki gejala yang dianggap tidak dapat reda dengan mengkonsumsi obat yang dapat diakses di apotek. Lugalla et al. (2012) menyatakan bahwa keputusan ODHA untuk melakukan tes sering tidak dibuat secara individu. ODHA memutuskan melakukan self-disclosure untuk meminta dukungan (Makoae et al., 2008). Untuk menghindari stigma dan penolakan, self-disclosure dilakukan oleh ODHA terbatas hanya pada orang-orang yang dianggap dapat dipercaya dan dapat memberikan perawatan yang diperlukan di antaranya petugas kesehatan dan keluarga (Hua et al., 2014).

Selain keinginan kuat dari ODHA, perawat juga berperan penting dalam mengarahkan ODHA untuk memperoleh pengobatan. Nursalam dan Kurniawati mengungkapkan perawat memiliki peran penting dalam mengarahkan ODHA untuk menggunakan koping yang konstruktif dalam beradaptasi dengan penyakitnya. Hasil penelitian diperoleh bahwa ODHA tergugah dengan arahan dari petugas kesehatan untuk melakukan pengobatan ke Puskesmas. Hal tersebut mengungkapkan bahwa dukungan yang diberikan oleh petugas kesehatan sangat mempengaruhi pengambilan keputusan dan tindakan ODHA untuk self-disclosure dan melakukan pengobatan.

Self-disclosure membantu ODHA memperoleh informasi yang benar mengenai penyakit HIV AIDS sehingga mengubah kesalahpahaman ODHA tentang penyakit HIV AIDS. Thompson et al. (2015) mengungkapkan bahwa ODHA www.jik.ub.ac.id 
perlu mengetahui prognosis penyakit HIV AIDS untuk mengubah kesalahpahaman ODHA tentang cara penularan penyakit HIV AIDS, melindungi pasangan dan orang yang dicintai, mencegah penularan dari ibu ke anak, meningkatkan kesadaran pentingnya pengobatan. Self-disclosure juga membantu ODHA memperoleh saran untuk terus berobat dari petugas kesehatan. Yonah et al. (2014) mengungkapkan self-disclosure membantu ODHA mendapatkan dukungan emosional, akses terhadap pengobatan dan perawatan. Self-disclosure juga dapat memberikan kesempatan ODHA untuk mengekspresikan pikiran dan perasaan (Chaudoir \& Fisher, 2010).

Dukungan dari petugas kesehatan sangat penting untuk menjaga kesehatan fisik dan mental ODHA. Dukungan tersebut dapat berupa dukungan emosional, informasi tentang penyakit serta dukungan perawatan (Chen et al., 2007; Qiao et al., 2015). Melalui informasi yang diperoleh dari petugas kesehatan mengenai penyakit HIV AIDS dan saran untuk terus berobat mempengaruhi kondisi batin ODHA. Hasil penelitian diperoleh bahwa ODHA merasa terbebas dari tekanan setelah self-disclosure. Hal tersebut juga diungkapkan oleh Majumdar dan Mazaleni (2010) dalam penelitiannya bahwa ODHA merasa jauh lebih baik setelah melakukan pengungkapan dan memiliki perasaan yang baik tentang masa depan. Thompson et al. (2015) mengungkapkan dukungan emosional dapat membantu ODHA menerima kondisi yang dialami, berkurangnya perasaan takut dan menarik diri dari masyarakat. Selfdisclosure dilaporkan membantu ODHA melepaskan tekanan psikologis dan berpotensi pada perubahan hidup yang positif (Norman et al., 2007).

Perasaan bebas dari tekanan dan saran yang diterima dari petugas kesehatan membangkitkan semangat ODHA untuk melakukan kegiatan yang dapat meningkatkan kualitas hidup dengan cara menjalani pengobatan, bergabung dalam kelompok dukungan, dan membantu orang lain. Qiao et al. (2015) mengungkapkan dukungan dari petugas kesehatan memiliki dampak positif terhadap kepatuhan pengobatan pasien dan peningkatan kualitas hidup. Keterlibatan ODHA dalam kelompok pendukung dapat mengurangi ketakutan, depresi, kesepian, dan isolasi. Kelompok pendukung memberikan lingkungan yang mendukung bagi ODHA untuk mengekspresikan perasaan (Paudel \& Baral, 2015). Kegiatan berbagi pengalaman dengan sesama ODHA membuat ODHA merasa tidak sendiri, perasaan lebih baik, dan melupakan rasa sakit yang disebabkan penyakit HIV AIDS (Makoae et al., 2008).

Penelitian ini memiliki keterbatasan dimana 
penelitian ini tidak mencari bagaimana partisipan melakukan self-disclosure. Penelitian ini juga tidak mencari perbedaan antara ODHA yang melakukan self-disclosure secara sukarela dengan ODHA yang melakukan self-disclosure atas dorongan baik petugas kesehatan maupun keluarga. Penelitian ini juga berfokus pada pengalaman ODHA menjalani self-disclosure kepada petugas kesehatan sehingga tidak mengungkapkan secara detail mengenai bagaimana pengalaman ODHA melakukan self-discolsure pada selain petugas kesehatan sehingga diperlukan penelitian lebih lanjut mengenai pengalaman ODHA menjalani selfdisclosure selain kepada petugas kesehatan.

\section{DAFTAR PUSTAKA}

Bidang Penyehatan Lingkungan dan Pengendalian Penyakit Dinas Kesehatan Provinsi Jawa Barat. 2012. Profil Kesehatan Provinsi Jawa Barat Tahun 2012. Bandung. Diakses pada tanggal 5 Maret 2016.

Bird, J.D.P., and Voisin, D.R. 2013. "You're an open target to be abused": A qualitative study of stigma and HIV self-disclosure among black men who have sex with men. American Journal of Public Health. 103(12): 2193-2199. doi: 10.2105/AJPH.2013.301437.

\section{KESIMPULAN}

Pengalaman ODHA dalam menjalani selfdisclosure merupakan proses yang tidak mudah. Keseluruhan proses yang dilalui oleh ODHA dari tidak memahami penyakit HIV AIDS, mengalami masalah kesehatan fisik dan penderitaan batin hingga muncul harapan dan ODHA memutuskan untuk mencari dukungan, memahami penyakit HIV AIDS, menjalani pengobatan dan melakukan kegiatan untuk meningkatkan kualitas hidup dapat diinterpretasikan bahwa makna pengalaman ODHA dalam menjalani self-disclosure adalah dari keterpurukan menyandang ODHA menuju peningkatan kualitas hidup.

Chaudoir, S.R., and Fisher, J.D. 2010. The disclosure processes model: Understanding disclosure decisionmaking and post-disclosure outcomes among people living with a concealable stigmatized identity. Psychol Bull. 136(2): 236-256. doi:10.1037/a0018193.

Chaudoir, S.R., Fisher, J.D., and Simoni, J.M. 2011. Understanding HIV disclosure: A review and application of the sisclosure processes model. Social Science \& Medicine. 72(10): 16181629. 
doi:10.1016/j.socscimed.2011.03.028

Chen, W.T., Starks, H., Shiu, C.S., FredriksenGoldsen, K., Simoni, J., Zhang, F., Pearson, C., and Zhao, H. 2007. Chinese HIV-positive patients and their healthcare providers. ANS Adv Nurs Sci. 30(4): 329-342. doi: 10.1097/01.ANS.0000300182.48 854.65 .

Devito, J.A. 2013. The Interpersonal Communication Book. Thirteenth edition. Pearson. New York. p. 55-65. Hua, J., Emrick, C.B., Golin, C.E., Liu, K., Pan, J., Wang, M., Wan, X., Chen, W., and Jiang, N. 2014. HIV and stigma in Liuzhou, China. AIDS Behav. 18(Suppl 2): S203-S211. doi: 10.1007/s10461013-0637-3.

Lilis, H. 2015. Kasus HIV AIDS Indramayu Tertinggi Kedua Di Jabar. http://www.republika.co.id/berita/n asional/umum/15/12/01/nyo6bm35 9-kasus-hivaids-indramayu-tertinggikedua-di-jabar. Indramayu. Diakses pada tanggal 6 Maret 2016.

Lugalla, J., Yoder, S., Sigalla, H., and Madihi, C. 2012. Social context of disclosing HIV test results in Tanzania. Culture, Health \& Sexuality. 14(S1): S53-S66. doi.org/10.1080/13691058.2011.615 413.
Majumdar, B., and Mazaleni, N. 2010. The experiences of people living with HIV/AIDS and of their direct informal caregivers in a resource-poor setting. Journal of the International AIDS Society. $\quad 13(20): \quad 2-9$. doi: 10.1186/1758-2652-13-20.

Makoae, L.N., Greeff, M., Phetlhu, R.D., Uys, L.R., Naidoo, J.R., Kohi, T.W., Dlamini, P.S., Chirwa, M.L., and Holzemer, W.L. 2008. Coping with HIV/AIDS stigma in five African countries. J Assoc Nurses AIDS Care. 19(2): 137146. doi: 10.1016/j.jana.2007.11.004. Norman, A., Chopra, M., and Kadiyala, S. 2007. Factors related to HIV disclosure in 2 South African communities. American Journal of Public Health. 97(10): 1775-1781. doi:10.2105/AJPH.2005.082511.

Nursalam dan Kurniawati, N.D. 2007. Asuhan Keperawatan Pada Pasien Terinfeksi HIV/AIDS. Edisi pertama. Salemba Medika. Jakarta. p. 2-53.

Paudel, V., and Baral, K.P. 2015. Women living with HIV/AIDS (WLHA), battling stigma, discrimination and denial and the role of support groups as a coping strategy: a review of literature. Reproductive Health. 
12(53): 2-9. doi: 10.1186/s12978015-0032-9

Qiao, S., Nie, J.B., Tucker, J., Rennie, S., and Li, X.M. 2015. The role of social relationship in HIV healing and its implications in HIV cure in China. Health Psychol Behav Med. 3(1): 115127.

doi: $10.1080 / 21642850.2015 .1040405$

Rahmati-Najarkolaei, F., Niknami, S., Aminshokravi, F., Bazargan, M., Ahmadi, F., Hadjizadeh, E., and Tavafian, S.S. 2010. Experiences of stigma in healthcare settings among adults living with HIV in the Islamic Republic of Iran. J Int AIDS Soc. 3(27): 1-11. doi: 10.1186/1758-2652-13-27.

Rouleau, G., Côté, J., and Cara, C. 2012. Disclosure experience in a convenience sample of quebec-born women living with HIV: A phenomenological study. $B M C$ Women's Health. 12(37): 1-11. doi:10.1186/1472-6874-12-37.

Streubert, H.J., and Carpenter, D.R. 2011. Qualitative Research In Nursing: Advancing The Humanistic Imperative. Fifth edition. Lippincott Willian \& Wilkins. Philadelphia. p. 47-85.

Stutterheim, S. E., Sicking, L., Brands, R., Baas, I., Roberts, H., van Brakel, W. H., and Bos, A. E. R. 2014. Patient and provider perspectives on HIV and HIVrelated stigma in Dutch health care settings. AIDS Patient Care and STDs. 28(12): 652-665. doi: 10.1089/apc.2014.0226.

Stutterheim, S.E., Sicking, L., Baas, I., Brands, R., Roberts, H., van Brakel, W.H., Lechner, L., Kok, G., and Bos, A.E.R. 2016. Disclosure of HIV status to health care providers in the Netherlands: A qualitative study. Journal of the Association of Nurses in AIDS Care. 27(4): 485-494. doi: 10.1016/j.jana.2016.02.014.

Thomas, B., Nyamathi, A., and Swaminathan, S. 2009. Impact of HIV/AIDS on mothers in Southern India: A qualitative Study. AIDS Behav. 13(5): 989-996. doi:10.1007/s10461-0089478-x.

Thompson, J., Havenga, Y., and Naude, S. 2015. The health literacy needs of women living with HIV/AIDS. Healths Age Sondheid. 20(1): 11-21. doi.org/10.1016/j.hsag.2015.03.001

Yadav, S. 2010. Perceived social support, hope, and quality of life of persons living with HIV/AIDS: A case study from Nepal. Qual Life Res. 19(2) :15766. doi: 10.1007/s11136-009-9574-z. 
Yonah, G. Fredrick, F., and Leyna, G. 2014. HIV serostatus disclosure among people living with HIV/AIDS in
Mwanza, Tanzania. AIDS Research

and Therapy. 11(5): 1-5. doi:10.1186/1742-6405-11-5. 